\title{
A SOCIOLOGIA POLÍTICA DO \\ RECONHECIMENTO: as contribuições de Charles \\ Taylor, Axel Honneth e Nancy Fraser \\ Patrícia Castro Mattos
}

Curso: Doutorado em Sociologia

Data de defesa da tese: 26 de abril de 2004

Orientadora: Prof ${ }^{\mathrm{a}} \mathrm{Dr}^{\mathrm{a}}$ Maria Francisca Pinheiro Coelho

\section{Resumo}

O objetivo central da tese é discutir como a teoria do reconhecimento passa, atualmente, a ser vista como uma nova possibilidade de interpretação para a teoria crítica. A mudança na perspectiva dos novos movimentos sociais, a queda da importância política e econômica do Socialismo, bem como uma reação aos paradigmas formalizados e reificados de enorme influência teórica e prática militam em favor de uma teoria crítica alternativa, que promete novas interpretações, diagnoses e formulações para os problemas das sociedades contemporâneas. São analisadas as teorias propostas por três autores centrais que trabalham, cada um a seu modo, o tema do reconhecimento social - o filósofo Charles Taylor, o sociólogo Axel Honneth e a cientista política Nancy Fraser.

A discussão sobre os pontos de coincidência e de divergência do debate entre eles é de relevante importância para o entendimento das questões centrais do tema do reconhecimento social e do capitalismo contemporâneo. A forma original como Taylor e Honneth recuperam e reinterpretam Hegel com desdobramentos diferenciados na política, bem como o debate entre Honneth e Fraser sobre os conflitos contemporâneos e as diferentes compreensões deles em relação ao entrelaçamento da economia e da cultura possuem 
importância basilar para uma teoria geral alternativa do mundo moderno em vias de "ocidentalização".

Os três autores contribuem para mostrar que a teoria crítica continua viva e que é necessário romper com os compromissos pseudoinevitáveis e pseudonaturais que negam que a força da reflexão pode mudar a nós mesmos e o mundo à nossa volta.

Palavras-chave: reconhecimento, teoria crítica, conflitos contemporâneos. 